Social Work Kononchuk, D. (2018). Kpprepii i noxasuman безпечної поведінки підлітків при здійсненні \& Education соціально-педагогічної підтримки вихованців в умовах оздоровчого табору, Social Work and Education, Vol. 5, No. 1., pp. 29-37.

๑ SW\&E, 2018

\section{Danylo Kononchuk,}

The postgraduate student of the pedagogical department,

Nizhin State University named after Mykola Gogol,

Nizhin, Ukraine

Danylo_Kononchuk@i.ua

\section{Данило Конончук,}

Аспірант кафедри педагогіки,

Ніжинський

державний

університет імені Миколи Гоголя. м. Ніжин, Украӥна

УДК 37.013 .42

DOI: $10.25128 / 2520-6230.18 .1 .3$

Article history:

Received: Febuary 27, 2018

1st Revision: March 17, 2018

Accepted: March 27, 2018

\section{КРИТЕРІЇ І ПОКАЗНИКИ БЕЗПЕЧНОЇ ПОВЕДІНКИ ПІДЛІТКІВ ПРИ ЗДІЙСНЕННІ СОЦІАЛЬНО- ПЕДАГОГІЧНОЇ ПІДТРИМКИ ВИХОВАНЦІВ В УМОВАХ ОЗДОРОВЧОГО ТАБОРУ} України, політичні перетворення, культурні трансформації, розвиток i поширення інформаційних технологій, зростання соціальної ролі та значення вільного часу як простору самореалізації особистості, високий динамізм вільного часу, поява нових форм проведення дозвілля є факторами, які вказують на гостру необхідність педагогічної підтримки процесу формування у дітей та молоді безпечної, відповідальної поведінки. Підлітки у прагненні до самовираження i самоствердження важаються найбільш вразливої категорією дітей, які потребують соціально-педагогічної підтримки. Часто це $\epsilon$ причиною їх потрапляння у складні життєві ситуації, що мають важкі наслідки для їхнього здоров`я та благополуччя, i $\epsilon$ перумовою формування різних проявів ризикованої поведінки. Під соціально-педагогічною підтримкою підлітків розуміють діяльність соціального педагога, спрямовану на створення умов, сприятливих для розвитку у них задатків і здібностей, визначення життєвої мети, прагнень, усвідомлення проблем і можливостей та на формування умінь, навичок щодо подолання власних проблем. В контексті безпечної поведінки - формування відповідального ставлення до свого життя i наслідків власних дій та вчинків у різних життєвих ситуаціях $\mathrm{i}$ середовищах. У контексті здійснюваного дослідження висвітлено особливості соціально-педагогічної підтримки безпечної поведінки підлітків; схарактеризовано принципи здійснення соціально-педагогічної підтримки та розроблено критерії та показники оцінки безпечної поведінки підлітків, що дозволило виявити рівні сформованості безпечної поведінки підлітків 3 метою підвищення ефективності соціально-педагогічної діяльності у цьому напрямі в умовах оздоровчого табору.

Ключові слова: безпечна поведінка; підлітки; соціально-педагогічна підтримка безпечної поведінки підлітків; критерії і показники; рівні безпечної поведінки підлітків. 


\section{Вступ}

У наш час все більшої популярності набуває організація відпочинку, оздоровлення, змістовного дозвілля підлітків в умовах оздоровчого табору чи літнього майданчика при ЗНЗ. Це не тільки позитивно впливає на їх фізичний стан, а й допомагає віднайти нові можливості для спілкування, праці, проведення вільного часу, розвитку інтересів та творчої самореалізації. Разом 3 тим, перебування в оздоровчих таборах може нести труднощі і ризики, які пов'язані зі зміною соціального оточення, факторів впливу, соціальної ситуації формування особистості. Оскільки у підлітковому віці діти прагнуть відчути себе самостійними і дорослими, то виникає нагальна потреба постійного порівняння й ідентифікації 3 однолітками, дорослими, самоспостереження із самовдосконаленням. Але, на жаль, часто підлітки не вміють передбачати наслідки своїх дій для себе і для соціуму, внаслідок чого можуть виникати порушення здоров'я або інші загрози для них самих або тих, хто їх оточує. Все це вимагає педагогічної підтримки формування у підлітків поведінки, яка б відображала відповідальне ставлення до свого життя і наслідків власних дій та вчинків у різних життєвих ситуаціях і в різних середовищах і визначається науковцями як безпечна. Прикладами такої поведінки є здоровий спосіб життя, уникання ризикованих ситуацій, дотримання соціальних норм, вибір друзів 3 гарною репутацією, відсутність різноманітних залежностей. (Алєксєєнко Т.Ф., 2009, с. 343).

Актуалізація питання формування безпечної поведінки підлітків також обумовлена соціально-економічними змінами, культурними трансформаціями, розвитком інформаційно-комунікаційних технологій, зростанням ролі вільного часу як простору самореалізації особистості. Ці та інші фактори вказують на гостру необхідність у правильній організації форм, методів і способів проведення дозвіллєвої діяльності, яка б йшла на користь молодому поколінню, сприяючи розвитку про-соціальних якостей. Значним чинником у цьому процесі для підлітків сьогодні виступають дитячі оздоровчі табори. Це стає можливим за умови як врахування сучасних особливостей виховного середовища дитячого оздоровчого табору, так і соціальної ситуації формування особистості у підлітковому віці, що дозволяє робити акцент на розвитку особистості вихованців як суб'єктів педагогічної взаємодії в системі «вихованець-вихованець» та «вихованець-педагог». На сьогодні дитячі оздоровчі табори займають вагоме місце в системі безперервного соціального виховання. Після деякого спаду в перші роки становлення української держави їх мережа постійно відновлюється, виникають нові типи дитячих оздоровчих закладів, змінюються терміни функціонування, форми власності та підпорядкування (Філоненко О.С., 2013).

\section{Аналіз останніх публікацій}

На сучасний стан організації соціально-виховної роботи 3 дітьми істотно впливають концептуальні положення теорії виховання дітей і молоді (І.Бех, І.Зязюн, О.Киричук, Р.Рибалко, М.Стельмахович, О.Сухомлинська, та ін.), дослідження соціалізації особистості загалом, і в підлітковому віці, зокрема, ( О.Безпалько, Л.Виготський, Н.Жигайло, I Кон, А.Мудрик, С.Харченко та ін.). 
Питання розробки теоретичної бази позашкільної та позакласної виховної роботи знаходимо у наукових працях В.Балахтар, Л.Балясної, В.Вербицького, В.Оржеховської, Т.Сущенко, Т.Цвірової та ін. Особливості професійнопедагогічних та виховних аспектів роботи з дітьми в умовах оздоровчого табору та підготовки майбутніх педагогів до діяльності в умовах дитячого оздоровчого закладу в Україні стали предметом наукових розвідок Л.Іванової, М.Наказного, Л.Пундик, О.Філоненко, С.Цуприк, Г.Шутки, О.Яковлєвої та ін.

За результатами педагогічних (Н. Анохіна, Л. Сорокіна та ін.) i психологічних (О. Войскунський, Т. Наумова, В. Фатурова та ін.) досліджень можна стверджувати, що найбільш вразлива категорія дітей, які потребують соціально-педагогічної підтримки $є$ підлітки, діяльність яких спрямована на задоволення потреби самовираження і самоствердження. Ця потреба спричиняє потраплянню підлітків у складні життєві ситуації, які можуть мати важкі наслідки для їхнього здоров `я та благополуччя, а також їх оточення; формує різні прояви ризикованої поведінки (шкідливі звички, розвиток алкоголізму, наркоманії, вагітність неповнолітніх, захворювання на ВІЛ/СНІД тощо). У зв`язку з цим актуалізується проблема формування безпечної поведінки підлітків, різні аспекти якої висвітлено у працях Т.Алєксєєнко, Р.Васильєвої, С.Гвоздій, Н.Зимівець, О.Жабокрицької, Л.Карнаух, В.Купєцької, Л.Сидорчук, Л.Сорокіної, М.Снітко та інших. Ми визначаємо соціально-педагогічну підтримку підлітків як діяльність соціального педагога, спрямовану на створення умов, сприятливих для розвитку у них задатків та здібностей, визначення життєвої мети, реальних прагнень, усвідомлення своїх труднощів, проблем, можливостей, лінії розвитку та на формування умінь, навичок щодо їх подолання, вирішення власних проблем, а в контексті безпечної поведінки - формування відповідального ставлення до свого життя i наслідків власних дій та вчинків у різних життєвих ситуаціях $\mathrm{i}$ середовищах. Ï̈̈ метою $є$ дієва допомога соціального педагога у адаптації та розвитку особистості, оволодіння нею нормами і правилами життя в суспільстві, знаннями і уміннями будувати стосунки у ньому, набутті таких характеристик як творчий характер життєдіяльності, можливість самостійно проектувати своє майбутнє і нести за це відповідальність. Особливості соціально-педагогічної підтримки безпечної поведінки: превентивна спрямованість; адресний характер; сприяння в адаптації особистості до умов соціального середовища; актуалізація особистісних ресурсів. Принципами здійснення соціально-педагогічної підтримки є: загальність, суб'єктність і індивідуальність, проблемність, пріоритет захисту прав та інтересів дитини, адресність й дозованість допомоги, співпраця й угода між дитиною та дорослим, систематичність підтримки, диференційованість підходу. Але, незважаючи на значну кількість наукових розробок у педагогічній науці, проблема формування безпечної поведінки підлітків в умовах оздоровчих таборів $є$ малодослідженою, хоча варто зазначити, що саме перебування у таких закладах $є$ продовженням в літній період формування дитини як суб'кта життя, розуміння нею того факту, що вона сама творить своє гідне людини життя. Це потребує, насамперед, формування у вихованців ціннісного ставлення до себе як до особистості, до інших людей, їхніх вчинків, до природи, предметів, явищ, формування відповідальності за свою долю, за вміння розпоряджатися своїм 
життям як даром природи в соціальному, психологічному та біологічному розумінні, що є важливим завданням педагогів дитячого оздоровчого табору.

Мета статті - теоретично обгрунтувати критерії, показники та рівні сформованості безпечної поведінки підлітків в умовах оздоровчого табору. Ставимо наступні завдання: 1) визначити критерії і показники безпечної поведінки підлітків; 2) охарактеризувати рівні сформованості безпечної поведінки підлітків в умовах оздоровчого табору. Для розв'язання поставлених завдань було застосовано методи теоретичного аналізу наукових джерел, синтезу та узагальнення.

\section{Основна частина}

На нашу думку, ефективність роботи соціального педагога у оздоровчому таборі тісно пов'язана з безпечною поведінкою дітей, які відпочивають у даному закладі. Визначити рівень сформованості безпечної поведінки вихованців можна завдяки критеріям і показникам, що передбачають наявність у соціального педагога системи професійних знань, умінь, навичок, особистісних якостей, набутого досвіду соціально-педагогічної діяльності у контексті безпечної поведінки, які забезпечать його ефективну взаємодію із тимчасово сформованим дитячим колективом.

3 метою дослідження формування безпечної поведінки підлітків в умовах оздоровчого табору, нами були виділені відповідні критерії та показники. Поняття «критерій» (від грец. kriterion - засіб для переконання, мірило) у довідковій літературі визначається як відмітна ознака, на основі якої проводиться оцінка якого-небудь явища, дії, ідей; у теорії пізнання - мірило достовірності наших знань, їх відповідності об'єктивній реальності (Локшина С.М., 1977, с.149). А. Галімов зазначає, що «критерій виражає найзагальнішу сутнісну ознаку, на основі якої здійснюють оцінку, порівняння реальних явищ, при цьому ступінь вияву, якісна сформованість, визначеність критерію виражаються у конкретних показниках» (Галімов, А.В, 2004, с. 93). А. Бойко пропонує за об'єкт оцінювання брати структурні компоненти навчальної діяльності, а саме: змістовий, операційно-організаційний, емоційно-мотиваційний i визначає критерії 3 відповідними назвами (Бойко А.М., 1996). А. Алексюк вважає, що критеріями оцінювання можуть бути також: характер засвоєння вже відомого досвіду, якість виявленого підлітком знання, логіка мислення, аргументація, послідовність і самостійність викладу, культура мовлення, ступінь оволодіння вже відомими способами діяльності, уміннями і навичками застосування засвоєних знань на практиці,оволодіння досвідом творчої діяльності, якість виконання роботи та поведінкових реакцій у типових ситуаціях постійного вибору (Алексюк А.М., 1998). На думку С. Іванової критерії також мають відображати динаміку вимірюваної якості в просторі й часі та розкриватися через показники, за інтенсивністю прояву яких можна робити висновки про рівень сформованості певного критерію (Іванова С.В, 2010, с.153).

При обгрунтованості критеріїв сформованості безпечної поведінки підлітків в умовах оздоровчого табору ми також враховували змістове наповнення компонентів її структури. У нашому дослідженні ми виділяємо такі критерії, які 
визначають ефективність формування безпечної поведінки підлітків у оздоровчому таборі: 1) ціннісно-оцінний (знання про особливості безпечної поведінки та їі значення для збереження здоров'я та життя як цінності; розуміння сутності поняття «безпечної поведінки» та дотичних до неї понять, знання про ризиковану поведінку та її наслідки для здоров'я та життя власного і оточуючих); 2) мотиваційний-емоційний (самооцінка власної життєдіяльності, міра ізольованості, міра потреби у пошуках «гострих» відчуттів, визначення цінності здоров'я як пріоритетної сутності, умотивованість вибору практик безпечної поведінки, бачення власної ролі у попередженні ризикованої поведінки); 3) діяльнісно-поведінковий (пріоритети у виборі напрямів видів діяльності; способи організації власного дозвілля, уміння ідентифікувати ситуації ризику та уникати їх, уміння чинити опір негативним впливам середовища та соціуму, які пов'язані із небезпечною поведінкою; час, проведений у спілкуванні з ровесниками).

Кожний критерій розкривається через систему показників, які його характеризують. У великому тлумачному словнику сучасної української мови показник трактується, як свідчення, доказ, ознака чого-небудь (Бусел В.Т., 2005, с.49). В. Тернопільська й О. Дерев'янко зазначають, що показник - це кількісні або якісні характеристики сформованості якості, властивості, ознаки об'єкта, що вивчається, ступінь сформованості того чи іншого критерію (Білецька Г. А., 2014, с.265). Тому показниками безпечної поведінки підлітків ми визначили наступні:

1. Ціннісно-оцінний критерій включає в себе такі показники: систематизація знань про безпечну поведінку та застосування їх у щоденній життєдіяльності; рівень володіння отриманими знаннями та уміннями у повсякденному житті, їх глибина, стійкість та обсяг.

2. До показників мотиваційно-емоційного критерію відносимо: бажання не тільки безпосередньо конкретного підлітка притримуватись основ і правил безпечної поведінки, але й активно пропагувати безпечну поведінку серед своїх однолітків; інтереси до участі у заходах, спрямованих на формування безпечної поведінки; усвідомлення того, що проблеми ризикованої поведінки стосуються кожного з нас і вирішувати їх може і повинен кожен; мотивація щодо позитивних тенденцій у поліпшенні стану профілактики ризикованої поведінки в дитячому середовищі.

3. Показниками діяльнісно-поведінкового критерію є: щоденна діяльність підлітка та домінуючий вибір поведінки у різних ситуаціях постійного вибору, здатність ідентифікувати потенційно-небезпечні ситуації та попереджувати їх, реакції на поведінку дорослих та ровесників, організація свого дозвілля та переважні форми його проведення.

На основі виділених критеріїв і показників нами було визначено три рівні сформованості безпечної поведінки підлітків (високий, середній, низький) та представлено до них педагогічні характеристики (табл. 1). Рівень - це міра величини, розвитку, значущості чогось (Бусел В.Т., 2005, с.83 ). 
Таблиия 1

Критерії та показники рівнів безпечної поведінки підлітків

\begin{tabular}{|c|c|c|c|}
\hline & \multicolumn{3}{|c|}{ Зміст показників } \\
\hline Рівні & Високий & Середній & Низький \\
\hline Критерії & & & \\
\hline $\begin{array}{l}\text { Ціннісно- } \\
\text { оцінний }\end{array}$ & $\begin{array}{l}\text { У підлітка } \\
\text { сформовані чіткі } \\
\text { переконання та } \\
\text { орієнтації, щодо } \\
\text { цінностей безпечної } \\
\text { поведінки та } \\
\text { необхідності } \\
\text { слідування ії } \\
\text { основним } \\
\text { положенням }\end{array}$ & $\begin{array}{l}\text { У підлітка присутні } \\
\text { уявлення про поняття } \\
\text { безпечної поведінки, } \\
\text { проте ії вияв } \\
\text { ситуативний, цінност } \\
\text { безпеки власного } \\
\text { здоров'я не на } \\
\text { пріоритетному місці } \\
\text { у особистості }\end{array}$ & $\begin{array}{l}\text { У підлітка відсутні або } \\
\text { викривлені уявлення } \\
\text { про цінності безпечної } \\
\text { поведінки, оцінку } \\
\text { власних вчинків } \\
\text { стосовно ризикованої } \\
\text { поведінки суб'єктивна, } \\
\text { цінності безпечної } \\
\text { поведінки не мають } \\
\text { впливу на особистість }\end{array}$ \\
\hline $\begin{array}{l}\text { Мотиваційно- } \\
\text { емоційний }\end{array}$ & $\begin{array}{l}\text { У підлітка } \\
\text { сформована в повній } \\
\text { мірі культура } \\
\text { безпечної поведінки, } \\
\text { мотиваційні важелі її } \\
\text { коригування, } \\
\text { морально-етичні } \\
\text { якості особистості } \\
\text { безпечного типу; } \\
\text { підліток може } \\
\text { автономно } \\
\text { вирішувати різні } \\
\text { стресові ситуації й } \\
\text { діяти з метою } \\
\text { збереження власного } \\
\text { здоров’я і життя }\end{array}$ & $\begin{array}{l}\text { У підлітка присутні } \\
\text { неповні знання про } \\
\text { безпечну поведінку, } \\
\text { проте їх недостатньо } \\
\text { для прогнозування } \\
\text { наслідків більшості } \\
\text { небезпечних } \\
\text { ситуацій, наявне } \\
\text { загальне уявлення } \\
\text { про ризики та } \\
\text { можливості їх } \\
\text { уникнення, здатність } \\
\text { керувати своїм } \\
\text { емоційним станом у } \\
\text { стресових умовах } \\
\text { вибіркова }\end{array}$ & $\begin{array}{l}\text { У підлітка відсутні } \\
\text { знання про безпечну } \\
\text { поведінку, не } \\
\text { сформована потреба } \\
\text { дотримуватись правил } \\
\text { елементарної техніки } \\
\text { безпеки, навпаки } \\
\text { підліток проявляє різні } \\
\text { прояви ризикованої } \\
\text { поведінки, створюючи } \\
\text { небезпеки для здоров’я } \\
\text { та життя власного і } \\
\text { оточуючих }\end{array}$ \\
\hline $\begin{array}{l}\text { Діяльнісно- } \\
\text { поведінковий }\end{array}$ & $\begin{array}{l}\text { У підлітка наявна } \\
\text { чітка та усвідомлена } \\
\text { програма дій, } \\
\text { регуляція поведінки } \\
\text { на високому рівні, } \\
\text { сформована } \\
\text { відповідальність за } \\
\text { власні вчинки та } \\
\text { наслідки поведінки, } \\
\text { дії усвідомлені та } \\
\text { обдумані, особиста } \\
\text { поведінка відповідає } \\
\text { критеріям безпечної }\end{array}$ & $\begin{array}{l}\text { Підліток переважно } \\
\text { уникає небезпечних } \\
\text { ситуацій, але } \\
\text { розрізними } \\
\text { потенційно- } \\
\text { небезпечні без } \\
\text { сторонньої допомоги } \\
\text { не спроможний, } \\
\text { присутня часта } \\
\text { розбіжність у } \\
\text { попередніх намірах } \\
\text { та реальних діях }\end{array}$ & $\begin{array}{l}\text { У підлітка відсутні } \\
\text { внутрішні механізми } \\
\text { керування власними } \\
\text { діями та } \\
\text { відповідальність за } \\
\text { свої вчинки, прояви } \\
\text { безпечної поведінки у } \\
\text { більшій мірі випадкові, } \\
\text { ніж цілеспрямовані }\end{array}$ \\
\hline
\end{tabular}




\section{Висновки}

Отже, проведене дослідження дозволило нам обгрунтувати та розкрити сутність критеріїв та показників сформованості безпечної поведінки підлітків у оздоровчому таборі, які забезпечать можливість проведення моніторингових досліджень 3 даного питання. Перспективу подальших досліджень вбачаємо у застосуванні на практиці методів, які б дозволили в перевірити дієвість виділених критеріїв і показників та розробити систему заходів соціальнопедагогічної підтримки безпечної поведінки даної категорії вихованців в умовах оздоровчого табору.

\section{Література}

Алексюк, А.М. (1998). Педагогіка вищої освіти України. Історія. Теорія: підручник для студ. К.: Либідь, 560 с.

Алєксєєнко, Т.Ф. (2009). Соціальна педагогіка: словник-довідник. Вінниця: Планер, 542 с.

Алєксєєнко, Т.Ф., Кушнарьов С.В. (2013). Ризикована поведінка: посібник. Вінниця: ТОВ «Фірма «Планер», 172с.

Білецька, Г. А. (2014). Критерії, показники й рівні сформованості природничо-наукової компетентності майбутніх екологів. Освіта та педагогічна наука. Bun. 2. (163), 19-24.

Бойко, А. М. (1996). Оновлена парадигма виховання: шляхи реалізації: навч.- метод. посіб. К.: ІЗМН, 232c .

Бусел, В. Т. (2005). Великий тлумачний словник сучасної української мови (з дод. і допов. К.: Ірпінь: ВТФ «Перун», $1728 \mathrm{c}$.

Галімов, А. В. (2004). Теоретико-методичні засади підготовки майбутніх офіцерів-прикордонників до виховної роботи з особовим складом. Монографія. Хмельницький: Вид-во Наи. академії Державної прикордонної служби Украӥни ім. Б. Хмельницького, 376 с.

Іванова, С. В. (2010). Критерії та показники розвитку професійної компетентності вчителів біології в закладах післядипломної педагогічної освіти. Вісник Житомирськ. держ. у-ту. Пед. науки. (52), 152-156.

Локшина, С. М. (1977). Краткий словарь иностранных слов. Стереотип. М.: Русский язык., (5), 352 с.

Філоненко, О.С. (2013). Підготовка майбутніх учителів у вищих педагогічних навчальних закладах України до виховної роботи в літніх дитячих оздоровчих таборах ( друга половина XX ст. - початок XXI ст. ): aвтореф. дис... канд. пед. наук: 13.00.01. Переяслав-Хмельницький державний педагогічний університет ім. Г.Сковороди. Переяслав-Хмельницький, 24 с. 


\title{
CRITERIA AND INDICATORS OF SAFE BEHAVIOR IN THE IMPLEMENTATION OF SOCIO-PEDAGOGICAL SUPPORT FOR ADOLESCENTS IN A HEALTH CAMP
}

\author{
Danylo Kononchuk, the postgraduate student of the pedagogical \\ department, Nizhin State University named after Mykola Gogol, \\ Nizhin, Ukraine, \\ Danylo_Kononchuk@i.ua
}

\begin{abstract}
It is discovered the necessity of social and pedagogical assistance for adolescents' safe behavior driven by the following factors: social and economic changes, cultural transformation, developing information and communicative technologies, the increasing of spare time social role and the importance of spare time as the expanse for person's self-realization, high dynamics of youth spare time, presence of new forms leisure-time activities. All these factors highlight the objective need for pedagogical assistance to form adolescents' behavior that reflects responsible attitude towards their lives and the consequences in different life situations and environment and are defined by the scientists as safe.

It is emphasized the age-appropriated person's development during adolescence (the need in self-expression and self-affirmation), that contribute the adolescents to get into difficult life situations with dire consequences for their health and welfare and for their entourage forming various manifestations of risky behavior.

Different approaches towards understanding the content of the social and pedagogical assistance as a scientific category and a counselor of children activity are characterized. It is detected the correlation of the categories "assistance", "pedagogical assistance", "socio-pedagogical assistance".

It is defined the content of the adolescents' socio-pedagogical assistance as a counselor of children activity aimed at creating favorable conditions for the development the adolescents' abilities and talents, defining life goal, real aspirations, awareness of their difficulties, problems, possibilities, trajectory of development and shaping skills and abilities to overcome them, solving their own problems and in the context of safe behavior - forming the responsible attitude to their lives and the consequences of their acts and actions in different life situations and environment.

It was defined the aim, characteristics, structure, principles of socio-pedagogical assistance for adolescents' safe behavior as an area of socio-pedagogical activity The developed criteria of safe behavior of adolescents (value-estimating, motivationalemotional, activity-behavioral) and their indicators allow to determine the levels of formation of safe behavior of adolescents in order to increase the effectiveness of social and pedagogical activities in this area in the conditions of the health camp.
\end{abstract}

Keywords: assistance; pedagogical assistance; socio-pedagogical assistance; safe behavior; adolescents.

\section{References}

Alekseyenko, T. F. (2009). Social pedagogy: dictionary-directory. Vinnitsa: Glider, 542. 
Alekseyenko, T. F., Kushnarev, S. V. (2013). Risky Behavior: A Guide. Vinnytsya: LLC "Firm" Glider ", 172.

Aleksiuk, A. M. (1998). Pedagogics of Higher Education of Ukraine. History. Theory: The textbook for the studio. K.: Lybid, 560.

Biletska, G. A. (2014). Criteria, indicators and levels of formation of the natural and scientific competence of future environmentalists. Education and pedagogical science. Whip 2. (163), 19-24.

Boyko, A. M. (1996). Updated paradigm of education: ways of implementation: teaching method. manual K .: IZMN, 232.

Busel, V. T. (2005). Great Dictionary of Contemporary Ukrainian Language (from the Appendix and Papers: Irpin: VTF "Perun", 1728.

Filonenko, O. S. (2013). Preparation of future teachers in higher pedagogical educational institutions of Ukraine for educational work in summer children's health camps (second half of XX century - beginning of XXI century): author's abstract. Dis ... Cand. ped Sciences: 13.00.01. Pereyaslav - Khmelnytsky State Pedagogical University named after. G. Skovoroda Pereyaslav - Khmelnitsky, 24.

Galimov, A. V. (2004). Theoretical and methodological principles of preparation of future officers-border guards for educational work with personnel. Monograph. Khmelnitsky: Vt. Nats. Academy of the State Border Guard Service of Ukraine to them. B. Khmelnitsky, 376.

Ivanova, S. V. (2010). Criteria and indicators of development of professional competence of teachers of biology in institutions of postgraduate pedagogical education. Visnyk Zhytomyrsk. state u-th Ped science (52), 152-156.

Lokshina, S. M. (1977). A short dictionary of foreign words. Stereotype. M .: Russian language., (5), 352. 
